\title{
BITTER AND TWISTED? ON PERSONAL INJURY CLAIMS, PREDATORY FEES AND ACCESS TO JUSTICE ${ }^{1}$
}

Daleen Millard

BJuris LLB LLM LLD

Professor, University of Johannesburg

Yvette Joubert

$B A$ LLB LLM

Senior Lecturer, University of Johannesburg

\section{SUMMARY}

This article explores the nature and extent of contingency-fee agreements in light of Justin John Bitter NO v Ronald Bobroff \& Partners Inc $v$ The Road Accident Fund (Case Number 11069/13 (GLDJ)). The case in question viewed the nature of a contingency fee agreement and determined that a contingency fee agreement is only valid if it meets the requirements of the Contingency Fees Act 66 of 1997. In addition, the court expressed itself strongly against the use of the so-called "common law contingency agreement". This article analyses the case in question and then proceeds to evaluate the statutorily prescribed agreement. It argues that the Contingency Fees Act is not user-friendly and that the prescribed contingency fees agreement may be greatly improved by redrafting it in plain language. In addition, the new Legal Practice Act 2 of 2014 supports the sentiments that were expressed in the Bitter case, but as it does not repeal the Contingency Fees Act, problems with plain language and drafting of contingency fee agreements remain. While this article agrees with the Bitter case, it stresses that it is imperative for the contingency fee agreements to be redrafted in plain language, which implies an overhaul of the Contingency Fees Act. In the final instance it is recommended that even though contingency fee agreements are controversial, they do play an important part in providing indigent litigants with access to justice. These agreements should, however, be strictly enforced in order to ensure that clients are not exploited.

\section{INTRODUCTION}

A contingency fee agreement between a client and an attorney generally entails an understanding in terms of which the client undertakes to relinquish

\footnotetext{
This contribution is based on a paper that was delivered by Daleen Millard at the Private Law and Social Justice Conference that was held at the Nelson Mandela Metropolitan University in August 2014. Without the invaluable experience and practical knowledge of personal injury claims that was added by Yvette Joubert, this article would not have been possible. Many thanks to Marieke Ehlers for her patience with the formatting of this article.
} 
or pay a percentage of a settlement or award for damages that was made in his favour to the attorney. This means that the attorney bears the risk of failure of the case which includes the risk of not raising a fee as well as carrying the burden of the costs of litigation. Contingency fee arrangements are an exception to the general rule that a legal practitioner should not have a personal financial interest in the outcome of a matter. In personal injury litigation, this means that the attorney will typically instruct and remunerate expert witnesses such as medical experts and actuaries to substantiate the claim. The advantage of this for a client is that it is not necessary to pay large fees upfront in order to prove a case and this is beneficial as it can be seen as granting a client access to justice. In addition, law clinics are generally prohibited from conducting personal injury litigation, with the result that attorneys who literally finance these cases in many cases become a lifeline for indigent, incapacitated clients.

The disadvantage of such an arrangement is unfortunately that the parties are not on an equal footing so the potential for the attorney to abuse his position of power is a real concern. It may happen that a contingency agreement is drafted in such a way that it literally deprives the plaintiff of his much-needed compensation, with the result that he becomes a burden to the health-care system and even worse, leaving the attorney with fees that he did not earn.

In the recent case of Justin John Bitter NO $v$ Ronald Bobroff \& Partners Inc $v$ The Road Accident Fund ${ }^{2}$ the court was faced with one such a plaintiff who brought an action with the assistance of his curator against his attorney.

The objective of this article is to discuss the problem of contingency fees in the context of so-called common-law contingency fees and the Contingency Fees Act ${ }^{3}$ and to evaluate the effect of the Bitter case decision. Further objectives are to investigate the role of legal aid, law clinics, the Legal Practice $\mathrm{Act}^{4}$ and ultimately the approach taken by the courts in ensuring that personal injury actions are accessible to clients and that a fair balance is struck between attorney and client. This will be dealt with by firstly discussing the Bitter case. The discussion then turns to common-law contingency fees, the Contingency Fees Act, legal aid in South Africa and the recent Legal Practice Act. Alternative views on contingency fees will also be discussed in order to illustrate the controversial nature of this topic. Finally, this contribution aims to suggest remedies that will address the shortcomings in the present structure of contingency fees in personal litigation.

\section{BITTER CASE}

\section{Facts giving rise to the original third-party claim}

In casu the victim, Anthony, was injured in a motor-vehicle collision on 2 September 2007. He suffered multiple injuries as a result of the said

\footnotetext{
Case Number 11069/13 (GLDJ).

66 of 1997.

28 of 2014.
} 
collision, which rendered him a quadriplegic. The accident left him permanently paralysed from the chest down and having no movement in his legs, apart from muscle spasms. ${ }^{5}$ Furthermore, he has no bladder function, no movement in the fingers of his right hand and no wrist movement or sensation in his left arm. He can only feed himself with a spoon strapped to his right hand, and needs assistance to drink liquids. Overall, the victim is completely and permanently dependent on his parents. ${ }^{6}$ The attorney, Ronald Bobroff \& Partners Inc ("RBP"), reached a so-called contingency-fee agreement with Anthony's parents. This entitled them to deduct a certain amount from Anthony's settlement, and they are the first respondents in the matter, as the attorneys who rendered services to Anthony in relation to a claim for damages against the second respondent ("the RAF") in terms of the Road Accident Fund Act, 56 of 1996 ("the RAF Act").

\section{Relief sought}

The relief sought by the applicant against RBP is a declaratory order that the contingency agreement between RBP and Anthony's parents was unlawful, invalid and unenforceable on the same grounds as those that were found by the full bench of the North Gauteng Court in the cases of Juan Elize De La Guerre $v$ Ronald Bobroff \& Partners Inc ${ }^{8}$ and the South African Association of Personal Injury Lawyers $v$ The Minister of Justice and Constitutional Development and the Road Accident Fund ("SAAPIL') ${ }^{9}$ on 13 February 2013. ${ }^{10}$ The full bench in both these cases held that common-law contingency agreements between legal practitioners and their clients were in fact unlawful, invalid and unenforceable.

Based on these judgments the primary relief, which the applicant initially sought in the present application, was an order to the effect that an agreement relating to contingency fees between RBP and Anthony (as well as his parents) be declared to be invalid and unenforceable. In light of the Constitutional Court's decisions in this regard, RBP's counsel accepted that the contingency fee agreement between RBP and Anthony and his parents was unlawful, with the result that the declaratory relief was no longer an issue. $^{11}$

The applicant also sought related relief, namely an order that RBP delivers, within 30 days of an order by the court, a fully itemized and detailed accounting in the form of a "bill of costs", supported by the necessary vouchers, reflecting the reasonable fees and disbursements incurred by RBP in the case between Anthony and the RAF. ${ }^{2}$ This is on the basis that Anthony is entitled to demand taxation of such bill. In addition, the applicant sought an order that RBP should pay the applicant's attorneys in trust the

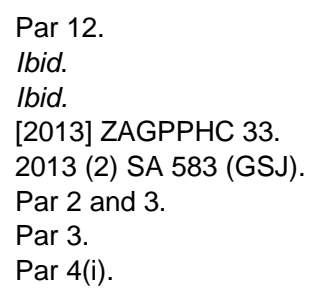


sum of R2 101871.80 that was retained by RBP as attorney and own-client costs. ${ }^{13}$

There was nothing unusual about the way in which this third-party claim proceeded. A pre-trial conference took place on 1 October 2010, although the minutes of the conference were not signed by either of the parties. ${ }^{14}$ In December 2010 the De Pontes received a "loan" from RBP in the amount of R50 000. ${ }^{15}$ The matter became settled on or about the trial date in November 2010, when the De Pontes accepted the Road Accident Fund's settlement offer in the amount of R6 145 824-05, plus agreed or taxed-party and party costs, which offer was made on 19 November 2010. The Road Accident Fund duly paid this capital amount into the trust account of RBP on 10 January 2011. On 4 February 2011 RBP accounted to their client, albeit on a partial basis, when they forwarded a cheque in the amount of R2 450000 to Anthony. ${ }^{16}$

On 30 March 2011 Anthony's mother e-mailed RBP, recording that she had been unsuccessfully trying to determine when final payment would be effected in the matter. On the same day she received a reply that final payment was not yet due to Anthony. This notwithstanding, RBP advised that an amount of R572 262-17 would be advanced in" full and final settlement" of the claim. ${ }^{17}$ This amount was arrived at by deducting the following from the settlement, namely: a $30 \%$ contingency fee (R2 101 871-80), the payment that was effected in February 2011 (R2 450 000), the "loan" which was forwarded in December 2010 (R50 000), and an amount of R971 690-05 due to the patient's medical aid, Discovery, thereby leaving a residue of $\mathrm{R} 572262-17 .^{18}$

In August 2011 RBP received an amount of R260 468-54 and from the Road Accident Fund in respect of their taxed party and party costs. They did not account to their clients in respect of this amount. In September 2011 Anthony's parents were informed by RBP that their fees were arrived at by applying a 30\% contingency to the capital received from the Road Accident Fund. $^{19}$

In the interim, Mrs de Pontes was aware of litigation taking place against RBP, namely the matter of Juan Elize De La Guerre $v$ Ronald Bobroff \& Partners, ${ }^{20}$ which was highly publicized in the media. ${ }^{21}$ Following the outcome of this matter on 13 February 2013, whereby the court declared common-law contingency fees to be inadmissible, she approached the attorney in that matter, namely Norman Berger and Partners ("NBP"), to represent her in a similar claim against RBP. In February 2013 she terminated RBP's mandate and then appointed NBP as her attorneys of

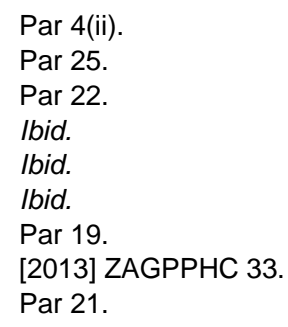


record on 6 February 2013. ${ }^{22}$ RBP were requested to hand over the De Pontes file to NBP on 8 February 2013 and, although they did not comply on the nominated date, the file was handed over at a later stage. On 7 March 2013 Mrs De Pontes brought an ex parte application to appoint Mr Bitter as curator ad litem to Anthony, which appointment was duly effected by Wepener J, on 12 March 2013. ${ }^{23}$ On 23 March 2013 Mr Bitter launched the application against RBP which is the subject of this judgment. ${ }^{24}$

On 2 April 2013 the founding application was served on RBP as the first respondent. The founding affidavit contained facts relating to Anthony's injuries and sequelae, as well as the settlement of the third-party claim, as set out above. The applicant alleged inter alia that the fee charged by RBP was "shockingly excessive and amounts to gross overreaching", and that a fair and reasonable fee for work done can only be determined by the drawing of an attorney and client bill to be taxed by the Taxing Master. It was on this basis that the relief was claimed.

\section{Respondent's response: attacking the locus standi of the curator}

RBP responded with a notice of opposition on 15 April 2013 and an answering affidavit on 14 May 2013. ${ }^{25}$ RBP opposed the relief claimed and raised a point in limine relating to the locus standi of the curator, alleging that the curator had been appointed without Anthony's knowledge and that, in any event, it had not been proved that he needed a curator. ${ }^{26}$ RBP was of the view that, notwithstanding the fact that Anthony was quadriplegic, he never sustained a head injury, was compos mentis and was thus able to manage his own affairs. ${ }^{27}$ On 28 May 2013 the applicant's replying affidavit was filed, and on the same date Anthony deposed to an affidavit stating that the curator had been appointed with his full consent. ${ }^{28} \mathrm{He}$ added that he and his parents had had no legal training and therefore trusted RBP implicitly. In reply, the applicant stated that RBP had no locus standi to challenge the appointment of the curator, that it was doing so merely to delay payment of its debt to Anthony, and that this amounted to an abuse of the court's process. $^{29}$

The matter was initially set down for 29 July 2013, but was postponed sine die, pending the outcome of the appeals in the De La Guerre and Saapil (South African Association of South African Personal Injury Lawyers $v$ The Minister of Justice and Constitutional Development and the Road Accident Fund 2013 (2) SA 583 (GSJ) CCT 122/13 and CCT 123/13) matters..$^{30}$ On 29 July 2013 these appeals were dismissed. The Bitter application was again

\footnotetext{
Par 22.

Par 7.

Par 8.

Ibid.

Par 28.

Ibid.

Par 30.

Par 38.

Par 8.
} 
set down for 29 July 2013, but was postponed. On the same date, RBP brought an application to rescind and set aside the appointment of Adv Bitter as curator on behalf of Anthony, which application was eventually heard on 9 September 2013. RBP's application was dismissed by Makhafola J, with punitive costs. Further appeals were noted in the De La Guerre and Saapil matters, this time to the Constitutional Court. On 20 February 2014 Constitution Court definitely pronounced that common-law contingency agreements were unlawful. ${ }^{3}$

On 11 March 2014 the Bitter application was set down for the roll during the week of 22 April 2014. On 28 March 2014 RBP launched an application in terms of Rule 30(1) to the effect that the application was irregular, as Makhafola J, was to hear an application on 25 April 2014 for leave to appeal of his dismissal of the application to set aside the appointment of the curator. The matter forming the subject of this judgment was heard on 23 April 2014. At the time RBP placed on record a "with prejudice" offer to pay NBP in trust the sum of R2 101 871-80 pending the payment of taxed or agreed costs. An unsuccessful attempt was made to serve this offer on Anthony personally, notwithstanding the fact that NBP were on record as his attorneys. ${ }^{32}$

\section{The court's decision and order}

The court was dealt with the issues in a fair and logical way. As far as the leave to appeal regarding the appointment of the curator is concerned, the court determined that there was no prejudice to RBP. In fact, they had no interest in the matter and the only motive was to delay payment of a debt to Anthony. ${ }^{33}$ This follows on to the point in limine relating to the locus standi of the curator. In this respect the court ruled that the appointment of the curator was based on Anthony's tragic and permanent physical limitations and was done with Anthony's knowledge and consent. RBP's contention that a curator is unnecessary is "untenable" and "insensitive", with the result that this point was not upheld. ${ }^{34}$

Par 3.

Par 35.

33 Par 37. More specifically, Mayat $\mathrm{J}$, ruled: "At the outset in relation to the application in terms of rule 30(1), I wish to state that this court cannot, of course, pronounce on the merits of the application for leave to appeal before Makhafola J. As such, submissions by counsel for the applicant pertaining to the appealability of the order of Makhafola $\mathrm{J}$ on the basis of the provisions of section 20 of the Supreme Court Act, 59 of 1959 are misdirected. I do, however, agree with counsel for the applicant that the application for leave to appeal the judgment of Makhafola $\mathrm{J}$, has no bearing on the present application, simply by virtue of the fact that the previous order of Wepener $\mathrm{J}$, relating to the appointment of Mr Bitter as curator to Anthony still remains in force. This is particularly so as the papers suggest no prejudice whatsoever to RBP if the order of Wepener $\mathrm{J}$, remains in force. Furthermore, even if Makhafola J, granted the application for leave to appeal at the instance of RBP, on the $25^{\text {th }}$ of April 2014, the previous order of Wepener J, still stands and the papers suggest no prejudice to RBP if the said order remains in force. In any event, contrary to the averments by RBP's counsel in the context of the present application, it is also my view that RBP had no direct and substantial interest in the order made by Wepener $\mathrm{J}$, nor was Mrs de Pontes obliged to give RBP notice of such application. This is particularly so as rule 57(2) specifically envisages an ex parte application for the appointment of a curator." Par 39.

$34 \quad$ Par 39. 
The more substantial issue of the illegality of common-law contingency fee agreements was argued vehemently by RBP. They contended that the illegality of such agreements were only definitely decided by the Constitutional Court in February $2014 .{ }^{35}$ In response the Court pointed out that our courts have consistently recognized that contingency fee arrangements which fall beyond the scope of the Act are contrary to public policy, unenforceable and unlawful. In this regard, reference was made inter alia to the judgment of Cameron J, in Price Waterhouse Coopers Inc and Others $v$ National Potato Co-Operative $L t d,{ }^{36}$ where it was said that the purpose of the Contingency Fees Act was to legitimize contingency fee arrangements which would otherwise be prohibited by common law. More specifically, the court states:

"Furthermore, as Fabricius J noted, both RBP as well as the Law Society of the Northern Provinces (the second respondent in the De La Guerre case) knew as far back as 1992, when former Chief Justice Corbett wrote a letter to the Natal Law Society that the learned Judge was prima facie of the view that contingency fee agreements between an attorney and his client would be unlawful in terms of the common law. A letter by Chief Justice Corbett's letter to the Natal Law Society in 1992 which expressed the view that contingency fee agreements between an attorney and his client would be unlawful in terms of the common law."

In addition, the court referred to Tjali $v$ Road Accident Fund, ${ }^{38}$ where it was held that the Contingency Act was intended to be exhaustive of the rights of legal practitioners to conclude contingency fee agreements with their clients.

The court then ruled on the repayment of monies, which was held to be the real issue in dispute. The court commented that RBP is entitled only to fair and reasonable costs for the services it rendered, and in the absence of a lawful agreement, the only way to determine such costs is by the rendering of a taxed or agreed attorney and client bill. ${ }^{39}$ There was therefore no legal basis for RBP to retain the money, and the RBP would suffer no prejudice if the money were to be paid in toto into the trust account of NBP. ${ }^{40}$ Although the order in the De La Guerre case only sought repayment of the difference between the sum unlawfully retained by RBP and the total of the taxed bill of costs, this was not the order requested in the case in hand, and the relief sought in each case will depend on the circumstances of that case ${ }^{41}$ In so far as this may lead to a opening of the floodgates of claims against RBP, this is not a concern of the present applicant, who had established his own case for repayment of the money. ${ }^{42}$

As far as costs are concerned, the court ruled that a punitive award of costs was warranted, based on a number of factors, namely RBP's delay in paying Anthony a portion of the capital sum, RBP's opposition of the

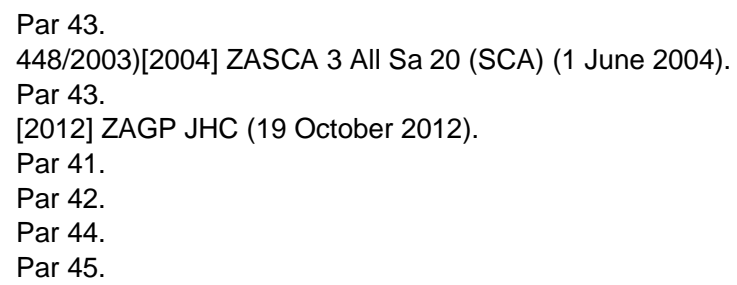


application primarily on technical grounds, the attempt to serve the settlement offer on Anthony personally, even though he was represented by attorneys, and the fact that these factors aggravated the unfortunate circumstances already suffered by Anthony. ${ }^{43}$

The court accordingly ordered RBP to deliver a fully itemized and detail bill of costs within 30 days of the order, to pay the amount of R2 101871-80 into the trust account of NBP pending agreement or settlement of RBP's bill of costs, to pay interest of $15.5 \%$ per annum from 1 April 2011 to date of payment on the difference between the amount originally retained and the agreed or taxed-fair and reasonable attorney and client fees. In addition, RBP was ordered to pay applicant's costs on attorney and own client scale, including the cost of two counsel.

\section{CONTINGENCY FEES: COMMON LAW V THE CONTINGENCY FEE}

The Contingency Fees Act, 66 of 1997 regulates contingency-fee agreements between attorneys and their clients. In terms of this act, attorneys need to complete an agreement that is prescribed by the Regulations in terms of the Act, reflecting, amongst other information, their hourly rate. The effect of this prescribed agreement is that an attorney is entitled to a contingency fee of up to a maximum of $25 \%$ of the capital amount of the claim or a bill of costs, whichever one is lesser. That means that if the capital amount is for example R 10000 , the attorney is entitled to a fee of R2 500 or the amount specified in the bill of costs, whichever is the lesser one. If the attorney-and-client bill of costs amounts to more than R2 500, the attorney is still only entitled to R2 500 .

Personal-injury lawyers have over the years developed a habit in terms of which they would enter into a so-called common-law agreement in terms of which they agree that $25 \%$ or more of the capital amount of the claim is payable to the attorney upon completion of the claim. They would typically argue that such a claim is allowed in terms of common law because the client entered into the agreement freely and voluntarily.

So-called common-law contingency agreements have received quite some attention by the courts. ${ }^{44}$ But as was pointed out in the discussion of the Bitter case above, the full bench of the North Gauteng Court in De La Guerre $v$ Ronald Bobroff \& Partners Inc. ${ }^{45}$ and in South African Association of South African Personal Injury Lawyers ("SAAPIL') $v$ The Minister of Justice and Constitutional Development and the Road Accident Fund held that so-called common-law contingency agreements between legal practitioners and their clients were unlawful, invalid and unenforceable.

43 Par 48.

44 Law Society of the Northern Provinces $v$ Mametsa (69558/2014) [2015] ZAGPPHC 396 (12 June 2015); Ntoni v Road Accident Fund (2158/2007) [2015] ZAECPEHC 34 (5 May 2015); Roux v Road Accident Fund (50133/2012) [2015] ZAGPPHC 285 (5 May 2015); De Kock v Road Accident Fund (3237/2013) [2015] ZAGPPHC 224 (22 April 2015); Makuapane v Road Accident Fund (2012/12871) [2015] ZAGPJHC 70 (10 April 2015); and Levenson $v$ Fluxmans Incorporated (14/27503) [2015] ZAGPJHC 68 (27 March 2015).

45 Check ref ([2013] ZAGPPHC 33) (13 February 2013). 
The full bench made it abundantly clear that the Contingency Fees Act left no room for contingency fee agreements which did not comply with the limitations of the Act. This means that contingency agreements of the kind concluded by RBP and other attorneys generally, as well as an agreement, which was the subject matter of the Da La Guerre case, were unlawful and invalid. These two precedents confirm that the primary relief which the applicant in Bitter initially sought, was an order declaring the agreement relating to contingency fees between RBP and Anthony invalid and unenforceable, and they also place the Bitter case in perspective: The court had no other option but to declare the common law fees agreement between Anthony's parents and RBP void.

The Contingency fees Act was enacted to regulate contingency fees agreements between legal practitioners and their clients. ${ }^{4}$

Section 2 of the Act provides that a legal practitioner may, if in his or her opinion there are reasonable prospects that his or her client may be successful in any proceedings, agree with such client that the legal practitioner shall not be entitled to any fees for services rendered unless the client is successful. In addition, the legal practitioner may charge fees higher than his or her normal fees, subject to the provisions of section 2(2). This section specifies that fees which are in fact higher shall not exceed such normal fees by more than 100 per cent. In addition, where the claim in question is for a sum of money, "the total of any such success fee payable by the client to the legal practitioner, shall not exceed 25 per cent of the total amount awarded or any amount obtained by the client in consequence of the proceedings concerned, which amount shall not, for purposes of calculating such excess, include any costs".

As far as the content of this agreement between the client and attorney is concerned, section $3(1)$ (a) stipulates that a contingency fees agreement shall be in writing and in the form prescribed by the Minister of Justice and published in the Gazette. It is the form that is in fact the subject of criticism in this article, but before this is discussed, it is important to note that a contingency fee agreement shall be signed by the client and, in accordance with section 3(3), the agreement must stipulate a number of things, namely

"(a) the proceedings to which the agreement relates;

(b) that before the agreement was entered into, the client -

(i) was advised of any other ways of financing the litigation and of their respective implications;

(ii) was informed of the normal rule that in the event of his, her or it being unsuccessful in the proceedings, he, she or it may be liable to pay the taxed party and party costs of his, her or its opponent in the proceedings;

(iii) was informed that he, she or it will also be liable to pay the success fee in the event of success; and

(iv) understood the meaning and purport of the agreement;

(c) what will be regarded by the parties to the agreement as constituting success or partial success;

(d) the circumstances in which the legal practitioner's fees and disbursements relating to the matter are payable;

46 Pre-amble to the Act. 
(e) the amount which will be due, and the consequences which will follow, in the event of the partial success in the proceedings, and in the event of the premature termination for any reason of the agreement;

(f) either the amounts payable or the method to be used in calculating the amounts payable;

(g) the manner in which disbursements made or incurred by the legal practitioner on behalf of the client shall be dealt with;

(h) that the client will have a period of 14 days, calculated from the date of the agreement, during which he, she or it will have the right to withdraw from the agreement by giving notice to the legal practitioner in writing: Provided that in the event of withdrawal the legal practitioner shall be entitled to fees and disbursements in respect of any necessary or essential work done to protect the interests of the client during such period, calculated on an attorney and client basis; and

(i) the manner in which any amendment or other agreements ancillary to that contingency fees agreement will be dealt with.

The act is very clear on the matters that need to be contemplated by the attorney and the client as well as the content of the actual agreement. In addition to the stipulations in section 3 of the Contingency Fees Act, the schedule to the Act contains the format in which the agreement should be coached.

It is submitted that the prescribed format is not in plain language and that in order to promote justice, this schedule should in fact be rewritten. Not only will this improve the client's understanding, but it will also better serve the purpose of the Contingency Fees Act, namely to effectively regulate the relationship between attorneys and their clients.

The current agreement is hard to understand and unfortunately the agreements between attorneys and clients on the one hand and those agreements with counsel are not clearly distinguished. It is suggested that the schedule should be redrafted. Although the agreement in its entirety is in dire need of redrafting, a number of clauses have been singled out to indicate how redrafting of the agreement in plain language may be beneficial:

The first significant portion of the agreement as per the schedule to the Contingency Fees Act stipulates as follows:

"1. It is recorded that in the opinion of the Attorney there are reasonable prospects that the Client may be successful in the proceedings mentioned hereunder and the Attorney therefore undertakes to recover no fees from the Client unless -

1.1 the Client is successful in such proceedings; or

1.2 the Attorney, as set out hereunder, becomes entitled to a fee in the event of partial success in such proceedings or in the event. of the premature termination of this agreement.

* Delete whichever is not applicable

** Delete if not applicable 2. It is further recorded that, before the signing of this agreement and in terms of section 3(3) of the Contingency Fees Act, 1997 (Act No. 66 of 1997), the Client was -

2.1 advised of any other ways of financing the litigation and of their respective implications, namely

2.2 informed of the normal rule that in the event of the Client being unsuccessful in the proceedings, he/she/it may be liable to pay the taxed party and party costs of his/her/its opponent in the proceedings; and 
2.3 informed that he/she/it will be liable to pay the success fee in the event of success, by the Attorney.

It is submitted that this portion may be simplified to read as follows:

"The client and the attorney agree on the following:

1. The client will pay the fees agreed to in this contract to the Attorney for services rendered, if the client is successful in the proceedings described in this agreement.

2. Attorney thinks that there is a good chance that the client may be successful in the proceedings mentioned hereunder.

3. The attorney will not charge the client any fees unless -

3.1 the client is successful in the proceedings; or

3.2 the attorney, may recover a fee if the the proceedings succeed partially or if the client terminates the agreement before the matter has been finalized."

In the same manner, the following portion of the statutory agreement is also cast in archaic terms that may confuse:

"4. The parties agree that the Client -

4.1 shall be deemed to be successful in the aforementioned proceedings if

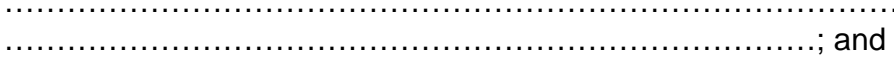

4.2 shall be deemed to be partially successful in the aforementioned proceedings if

5. The Attorney hereby warrants that the normal fees on an attorney and own client basis to perform work in connection with the aforementioned proceedings are calculated on the following basis: applicable rates)

6. The parties agree that if the Client is successful in the aforementioned proceedings -

** an amount of $\mathrm{R}$....................... shall be payable to the Attorney;

** an amount shall be payable to the Attorney, calculated according to the following method:

Nota bene: If the success fee is higher than the Attorney's normal fees, such higher fee may -

- not exceed the Attorney's normal fees by more than 100 per cent; and

- in the case of a claim sounding in money, not exceed 25 per cent of the total amount awarded or any amount obtained by the Client in consequence of the proceedings.

For purposes of calculating the higher fee, costs are not included.

* Delete whichever is not applicable.

** Delete if not applicable."

This portion will also benefit from redrafting and it is submitted that something to the effect of the following may enhance the client's understanding of the agreement:

"4. The parties record that, before the signing of this agreement and in terms of section 3(3) of the Contingency Fees Act, 1997 (Act No. 66 of 1997), the attorney:

4.1 advised the client of other ways of paying for the litigation and of the implications of these options, namely 
4.2 informed the client of the normal rule that if the client is unsuccessful in the proceedings, he/she/it may have to pay the taxed party and party costs of his/her/its opponent in the proceedings; and

4.3 informed the client that he/she/it will be liable to pay the success fee if the client is successful.

5. The client confirms that he/she/it gave a written power of attorney to the attorney to -

5.1 conduct proceedings in/before the ..................... (court of law/tribunal/functionary) having the power of a court of law to ............................................., on his/her/its behalf.

5.2 render professional services, namely ..... , to him/her/it.

5.3 conduct arbitration proceedings in/before the for the purpose of on his/her/its behalf."

Withdrawal from the agreement in terms of the current clause states as follows:

"9.1 The Client has a period of 14 days, calculated from the date of signing this agreement, during which he/she/it will have the right to withdraw from the agreement by giving notice to the Attorney in writing.

9.2 The Attorney shall, in the event of withdrawal by the Client, be entitled to fees and disbursements in respect of any necessary or essential work done to protect the interests of the Client during such period, calculated on an attorney and client basis."

It is suggested that it makes more sense to redraft this agreement as follows:

"9.1 The client may withdraw from this agreement within 14 days, calculated from the date of signing this agreement.

9.2 The client must give notice in writing if he wants to withdraw.

9.3 If the client withdraws, the attorney is entitled to fees and disbursements for any necessary work done to protect the interests of the client during such period, calculated on an attorney and client basis."

It is by no means suggested that one clause in the attorney-client agreement is more important than another, but in the same way that the clauses above have been simplified to explain the client's rights in no uncertain terms, it is suggested that clause 13 should also be redrafted. The current clause 10 reads as follows:

"10. If the Client feels aggrieved by any provision of this agreement or any fees chargeable in terms of this agreement, the agreement or the fees may be referred for review to the Law Society of which the Attorney is a member and, if an advocate has been appointed, also to the Bar Council in the area in which the advocate practises. The professional controlling body concerned may set aside any provision of this agreement or any fees claimable in terms of this agreement if in its opinion such provision or fees are unreasonable or unjust."

In plain language, the clause reads as follows:

"10.1 A client who is unhappy with any provision of this agreement or any fees chargeable in terms of this agreement, he/she/it may refer the matter for review to the Law Society of which the Attorney is a member.

10.2 The Law Society who has jurisdiction may set aside any provision of this agreement or any fees claimable in terms of this agreement if it is of the opinion that such provision or fees are unreasonable or unjust." 
A simpler agreement will help a client to understand exactly what he or she is in for. The fact that a client can enter into a contingency fee agreement actually promotes access to justice provided that the agreement is clear. The next paragraph shows that legal aid in South Africa is not permitted in personal injury cases, and because that is the case, contingency fee agreements are in actual fact the only way in which indigent clients can access the services of attorneys.

\section{$4 \quad$ LEGAL AID}

In South Africa, legal aid is regulated by statute and more specifically, by the Legal Aid South Africa Act. ${ }^{47}$ At first glance, it seems as though legal aid is ideally suited to protecting the interests of indigent clients who desperately need access to justice. In personal injury litigation there is a particular need for this. This idea is enforced by the pre-amble to the Act that provides that the purpose of the Act is "To ensure access to justice and the realisation of the right of a person to have legal representation as envisaged in the Constitution and to render or make legal aid and legal advice available." Section 3 of the Act reiterates this idea and stipulates that the objects of Legal Aid South Africa are to render or make available legal aid and legal advice,$^{48}$ to provide legal representation to persons at State expense, ${ }^{49}$ and to provide education and information concerning legal rights and obligations. ${ }^{50}$ In personal injury litigation it is specifically the first two objectives that are relevant. However, as legal representation as envisaged by this particular statute is essentially financed by taxpayers' money, the Minister of Justice is empowered by section 23 to publish regulations on the types of cases that may be dealt with by legal aid. It is evident from the Regulations that personal injury cases may not be dealt with by the Legal Aid Board. ${ }^{51}$ However, according to Legal Aid South Africa, "[l]f substantial injustice would otherwise result, legal aid is available for bringing claims against the Road Accident Fund and for bringing personal injury claims where a minor child is the claimant, assisted by his/her guardian." ${ }^{52}$ It therefore seems that legal aid is of limited use overall in personal injury litigation and that other matters are usually prioritized.

There are various reasons for this and one may argue the Minister's choice to prioritize family-law matters and criminal matters over personal injury cases, but be it as it may, as it stands at the moment, the Act does not promote access to justice for injured individuals who need urgent legal representation.

Legal aid in terms of the Act should not be confused with the activities of legal-aid clinics. The latter are normally affiliated with universities and they function as attorneys' firms for all intents and purposes. Clinics are recognized as independent, professional bodies in terms of sections 1 and

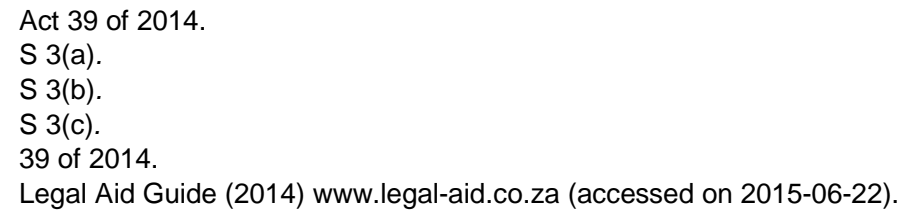


3(1)(f) of the Attorneys Act. ${ }^{53}$ The funding of these clinics depend on grants and throughout, a means test is applied to determine whether the particular clinic may take on a case. It can therefore happen that a particular clinic specializes in a particular flied of law. However, the respective law societies in South Africa as the overseeing authorities seem to have excluded personal injury litigation from the activities of law clinics. The Rules of the Law Society of the Northern provinces specifically mention litigation arising from motor-vehicle injuries (so-called road-accident fund claims) but even though all personal injury matters are not excluded, it is submitted that the complications that arise from funding the litigation cannot justify the handling of these types of claims. The result is that clinics refer clients to attorneys who conduct personal injury litigation and these attorneys inevitably enter into contingency-fee agreements. Again, while clinics play an important role in promoting social justice, their role does not extend to personal injury cases.

The other option is pro bono work. Pro bono literally means "for free" and attorneys have an obligation to conduct pro bono work. However, where a pro bono, unopposed divorce will probably not require more than a day or two's work, no personal injury case is ever that straightforward and again, the client's only option is to enter into a contingency-fee agreement with the attorney.

\section{THE LEGAL PRACTICE ACT $^{55}$}

\section{$51 \quad$ Introduction and overview}

The most recent development in the structure of the legal profession in South Africa is no doubt the promulgation of the Legal Practice Act. This statute aims to align the legal profession with the Constitution. ${ }^{56}$ It further aims to include the introduction of an independent legal profession regulated by a single Legal Practice Council that will set norms and standards to regulate the professional conduct of legal practitioners so as to ensure accountable conduct. ${ }^{57}$ The Act also deals with the handling of trust moneys. ${ }^{58}$

Of particular importance for this discussion is the investigations into legal fees and in this respect, section 35 of the Act envisages that the South

5353 of 1979.

54 The requirements for pro bono work differ from law society to law society. The Rules of the Law Society of the Northern Provinces (more specifically rule 79(A) contains stipulations regarding pro bono work. More specifically, rule 79A.2 stipulates as follows: "Practising members who have practised for less than 40 years and who are less than 60 years of age, shall, subject to being asked to do so, perform pro bono services of not less than 24 hours per calendar year."

5528 of 2014.

56 Preamle to the Legal Practice Act, 28 of 2014.

57 Ibid. Although not relevant to this article, it may be noted that the Act further makes provision In Chapters 5, 6 and 10 for the continuation of the Legal Practitioners Fidelity Fund and for the establishment of a Legal Services Ombud and a National Forum on the Legal Profession. Chapter 10 furthermore includes transitional provisions.

58 Chapter 7. 
African Law Reform Commission ("the Commission"), within a time period, ${ }^{59}$ must investigate and report back to the Minister with recommendations on certain aspects, including "unattainable" legal fees, improved access to justice and the establishment of a mechanism to determine fees and tariffs for legal practitioners. In particular, section $35(1)(e)$ and (f) requests the Commission to determine the desirability of giving users of legal services the option of voluntarily agreeing to pay fees for legal services less or in excess of the standard fees and tariffs to be set, and the obligation by the legal practitioner to conclude a mandatory fee arrangement with a client when that client secures that legal practitioner's services. In conducting the investigation, the Commission must consider best international practices, public interest, the interest of the legal profession and the use of contingency fee agreements as provided for in the Contingency Fees Act.

However, until the envisaged investigation by the Commission is contemplated, fees in respect of legal services must be in accordance with the tariffs made by the Rules Board for Courts of Law ("the Rules Board"). ${ }^{60}$ The Rules Board must, when determining the tariffs, take into account the following aspects: the importance, significance, complexity and expertise of the legal services required, the seniority and experience of the legal practitioner concerned, as determined by the Act, the volume of work required and the time spent in respect of the legal services rendered, and the financial implications of the matter at hand. ${ }^{61}$

Section 35(3) provides as follows:

"Despite any law to the contrary, nothing in this section precludes any user of litigious or non-litigious legal services, on his or her own initiative, from agreeing with a legal practitioner in writing, to pay fees for the services in question in excess of or below any tariffs determined as contemplated in this section."

The significance of this section is that it does not preclude the use of contingency-fee agreements as provided for in the Contingency Fees Act. In fact, it is doubtful whether this Act makes any difference whatsoever to the current practice of entering into a fee agreement. In fact, the new, statutorily prescribed practice of providing a client with a cost-estimate notice as per section 35(7) is a practice that is actually implied in the Contingency Fees Act. This particular section notes that when an attorney or advocate first receives instructions from a client for the rendering of legal services, they must provide the client with a cost-estimate notice, in writing, specifying "all particulars relating to the envisaged costs of the legal services." In addition, a number of other matters need to be disclosed, namely the likely financial implications including fees, charges, disbursements and other costs, the attorney's or advocate's hourly fee rate and an explanation to the client of his or her right to negotiate the fees payable to the attorney or advocate and an outline of the work to be done in respect of each stage of the litigation process. ${ }^{62}$ In addition, the attorney should inform the client of the likelihood

59 Within 2 years after the commencement of Chapter 2 of the Act. Chapter 2 establishes the South African Legal Practice Council.

60 Established by the Rules Board for Courts of Law Act, 107 of 1985.

61 S 35(2)(a) to (d).

62 S 35(7)(a)-(d). 
of engaging an advocate, as well as an explanation of the different fees that can be charged by different advocates, depending on aspects such as seniority or expertise and finally, if the matter involves litigation, the attorney should explain the legal and financial consequences of the client's withdrawal from the litigation as well as the costs-recovery regime. ${ }^{63}$

In addition to the written cost estimate, the attorney or advocate must also verbally explain to the client every aspect contained in the notice, as well as any other relevant aspect relating to the costs of the legal services to be rendered. A client must, in writing, agree to the envisaged legal fees and the incurring of the estimated costs. ${ }^{64}$ Non-compliance with the above provisions by the attorney or advocate constitutes misconduct ${ }^{65}$ and, further, the client is not required to pay any legal costs to that attorney or advocate until the Council has reviewed the matter and made a determination regarding amounts to be paid.

The Legal Practice Act provides extensively for disciplinary hearings and sanctions. Without discussing these provisions in too much detail, it may be noted that it is the duty of the disciplinary committee to conduct a hearing with a view to establishing whether a legal practitioner is guilty of misconduct. ${ }^{66}$ If found guilty of misconduct, the legal practitioner may be ordered to pay compensation to the complainant, ${ }^{67}$ be fined, ${ }^{68}$ temporarily suspended from practising ${ }^{69}$ or the Council may apply to the High Court to have him struck off, suspended from practice, interdicted from dealing with trust monies or other appropriate relief may be claimed. ${ }^{70}$ Further, the Council may amend or endorse his enrolment or his Fidelity Fund Certificate may be withdrawn. ${ }^{71}$ At the very least, the legal practitioner may be warned against certain conduct or cautioned/reprimanded. ${ }^{72}$ In addition to the sanctions referred to in subsection (3), subsection (4) notes that the disciplinary committee may order the legal practitioner to pay the cost of the investigation or the disciplinary hearing. Before one becomes excited over this, it is perhaps good to consider the criticism that was leveled against the law societies when issues pertaining to overreaching of clients first came to light. It is a fact that Mr Bobroff, Anthony's first attorney, was the chairperson of the Law Society for the Northern Provinces, and as such, should have known the rules pertaining to fees and contingencies. Furthermore, for a functionary in such a position to abuse his powers and to turn a blind eye for practices that were clearly harmful, is proof that any bureaucratic institution, including a council such as the one envisaged by the Legal Practice Act, is only as good as those who enforce the rules.

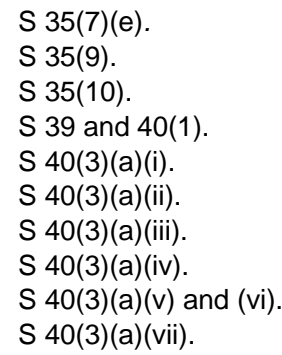


The Bobroff example is perhaps one of the best arguments against selfregulation. It is therefore perhaps a positive development that the Legal Practice Act introduces a Legal Services Ombud. ${ }^{73}$

The objects of the Ombud are to protect and promote the public interest in relation to the rendering of legal services as contemplated in the Act, to ensure the fair, efficient and effective investigation of complaints of alleged misconduct against legal practitioners, to promote high standards of integrity in the legal profession and to promote the independence of the legal profession. ${ }^{74}$ The powers of the Ombud include the power to investigate any complaint in respect of maladministration in the application of the Act, abuse or unjustifiable exercise of power or unfair or other improper conduct or undue delay in performing a function in terms of the Act or an act or omission which results in unlawful or improper prejudice to any person, which the Ombud considers may affect the integrity and independence of the legal profession and public perceptions in particular. ${ }^{75}$

Another innovation that can be said to promote access to justice is the new rules pertaining to the recovery of costs by legal practitioners rendering free legal services. Section 92(1) provides that when legal practitioners render a service free to a litigant, and costs become payable to that litigant in terms of a judgment of court or a settlement, the litigant must be deemed to have ceded his or her rights to the costs to that legal practitioner, law clinic or practitioner. ${ }^{76}$ This particular stipulation can be open to abuse. However, in light of the other stipulations of the Legal Practice Act it is submitted that this stipulation may perhaps encourage practitioners to assist indigent litigants in enforcing their rights.

An evaluation of the Legal Practice Act reveals that practitioners and especially attorneys are now forced to engage in a frank disclosure with their clients at the outset. It is, however, not new for contingency fee agreements. The Contingency Fees Agreements Act in fact presupposes negotiations between a client and an attorney, and especially where a contingency fee agreement was contemplated, the attorney as the professional was most definitely expected to explain to the client what the agreement entails and to explain the fees and provide an estimate of the costs. In the absence of such a disclosure a client would not have been able to grasp whether it is advantageous to enter into a contingency fees agreement. This is perhaps a long-winded way to state that the Legal Practice Act does not really introduce anything new where contingency fees are concerned. In cases such as unopposed divorces, this estimate will typically include the sheriff's fees, the advocate's fees, and the attorney's fees. However, in complicated matters, and specifically personal injury cases, it may be difficult, bordering on impossible, to foresee the complexities that may arise as the case progresses, and it is hoped that this will not detract from the efficacy of the cost estimate. It is submitted that, although there has always been a duty on attorneys to be ethical in taking instructions from clients and disclosing the client's duty in terms of fees, the Legal Practice Act now requires an attorney

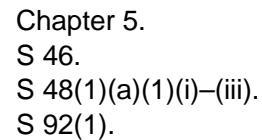


to keep record of his disclosures. Furthermore, it is submitted that if the client and the attorney decide that a matter is better managed in terms of a contingency-fee agreement, a proper interpretation of the Contingency Fees Act and the Legal Practice Act is required. It will make sense for the attorney to align the contingency agreement with the cost estimate that is required by statute, and to ensure that not only do these documents reflect the same fees but also that the client understands the full implications of the contingency-fee agreement.

\section{THE ROLE OF THE COURTS IN MAKING AND ENFORCING COST ORDERS}

Costs are generally awarded to parties to compensate them for the legal costs they were compelled to incur to enforce their rights, ${ }^{77}$ and as such are not intended to enrich legal practitioners. It is an insult to burden a client who had no choice but to endure the costs and stress of litigation, and who is vulnerable due to his lack of legal expertise, with an onerous attorney and client bill. A practitioner is nevertheless entitled to a reasonable fee for services rendered. ${ }^{78}$ The aim is to strike an equitable balance between attorney and client. $^{79}$ These basic rules pertaining to costs were stated in Ferreira $v$ Levin $N O{ }^{80}$ and according to Texas Co (SA) Ltd $v$ Cape Town Municipality ${ }^{81}$ the purpose of a cost award to a successful litigant is to

"indemnify him for the expense to which he has been put through having been unjustly compelled to initiate or defend litigation, as the case may be. Owing to the operation of taxation, however, such an award is seldom a complete indemnity; but that does not affect the principle on which it is based."

One can therefore deduct that costs are not a reward for the risk of litigation and should neither encourage nor discourage litigation. This is particularly so in matters involving personal injury where clients are often persuaded to instigate claims for compensation by practitioners who actively go out to canvas such work. Practitioners who mask their robust marketing under a veil of virtuously enabling access to court, have also been called to task by the Constitutional Court who stressed that the right belonged to the client, not the legal practitioner. ${ }^{83}$ Our courts have recognized that legal fees should be evaluated not only in terms of market rates, but should also be cognizant of our socio-economic circumstances. This was held in Camps Bay Ratepayers' and Residents' Association v Harrison ${ }^{84}$ as follows:

\footnotetext{
Texas Co (SA) Ltd v Cape Town Municipality 1926 AD 467488.

Camps Bay Ratepayers' and Residents' Association v Harrison 2012 JDR 1723.

President of the Republic of South African v Gauteng Lions Rugby Union 2002 (2) SA 64 (CC).

1996 (2) SA 621 (CC) 624B-C (par 3).

1926 AD 467488.

488.

83 South African Association of Personal Injury Lawyers $v$ Minister of Justice and Constitutional Development (Road Accident fund, Intervening Party 2013 (2) SA 583 (GSJ) par 2.

842012 JDR 1723. This judgment concerns counsel fees, but is nevertheless apposite to the discussion.
} 
"No doubt skilled professional work deserves reasonable remuneration, and no doubt many clients are willing to pay market rates to secure the best services. But in our country the legal profession owes a duty of diffidence in charging fees that goes beyond what the market can bear."

Our courts have shown that they will not shy away from addressing "skyrocketing" ${ }^{85}$ legal fees. Mojapelo DJP, has taken this a step further when he issued a practice directive in the Gauteng Local Division, Johannesburg underscoring this court's duty to monitor contingency fee arrangements: ${ }^{86}$ In terms of this directive the court, upon making a settlement agreement an order of court, has to request that the affidavit referred to in section 4 of the Contingency Fees Act must be filed if a contingency fee was agreed to. If no contingency agreement was entered into, the attorney and his client must file affidavits confirming this fact. Where a contingency-fee agreement was entered into, in addition, counsel must confirm to the court that counsel has read such agreement and advise the court whether same complies with the Act or not. The practice directive notes that the court may in its discretion call for the submission to it of the contingency-fee agreement for examination by the court. The attorney must confirm in his/her affidavit that he/she has explained to the client the client's right to take the agreement and the fees charged in terms thereof for review as contemplated in Section 5 of the Act; and the client must in his/her affidavit confirm the explanation and further, that he/she is in possession of the name, address and contact details of the relevant controlling professional body or bodies. Mojapelo confirmed that the court should assume a monitoring function where contingency-fee agreements are concerned. He stipulated that the court should call for and examine the agreement if it was a contingency-fee agreement, stating that attorney and client privilege does not operate against disclosure of the agreement and, even if it did, public policy deemed such disclosure necessary.

It is submitted that there are compelling arguments for stating that an agreement between an attorney and a client cannot be equated to any other kind of mandatum agreement. This is because the court always has a discretion in awarding costs on a party-and-party or attorney-and-client basis. ${ }^{87}$ Therefore, if it becomes evident that an attorney was not upfront and forthcoming with information about a contingency fee agreement or where it transpires that the contingency fee agreement is not clear, it may not be enforceable. It is trite that any contract contra to public policy is nil, void and

5 Camps Bay.

86 Mofokeng $v$ Road Accident Fund (unreported case no 22649/09); Makhuvele $v$ Road Accident Fund (unreported case no 19509/11); Mokatse v Road Accident Fund (unreported case no 24932/10); and Komme v Road accident Fund (unreported case no 20268/11 (GSJ (22-8-2912) Mojapelo DJP).

87 Theophilopoulos, Van Heerden and Boraine Fundamental Principles of Civil Procedure 3ed (2015) 445. The authors note that the successful party is generally entitled to a costs order in its favour, but that such a party may be deprived of costs if there is a good reason for this, and that a party may in exceptional circumstances be ordered to pay the other party's costs in circumstances including fraud, dishonesty, reckless, malicious or frivolous motives and grave misconduct. Costs de bonis propriis are costs to be paid by the attorney, not the client, when the court is of the opinion that the attorney has substantially deviated from the responsibilities of his office by acting mala fide, negligently or unreasonably (448). 
unenforceable. ${ }^{88}$ The court's discretion also includes a request that the cost estimate should be submitted together with the court papers. The Legal Practice Act does not change this discretion but rather aims to place the parties to a fee agreement on a more equal footing. Any abuse by an attorney of his position is therefore still subject to the court's supervision. ${ }^{89}$ This does not mean that the court suddenly has the power to rewrite an agreement between an attorney and his client but rather that costs are such an integral aspect of legal work, and more specifically litigation that this aspect can never be separated from the court's discretion. It is for this reason that the normal rules in South African law pertaining to pacta sunt servanda do not apply to agreements between attorneys and clients pertaining to fees.

The rules of court only make provision for legal costs to be determined by means of a tariff. No mention is made of an agreed fee or a contingency fee. $^{90}$ The tariff makes provision for consultations, appearances, conferences and inspections rated on a time scale. Hourly-based fee rates are subject to criticism on various grounds, two of the most obvious being that it is not always possible to foresee how many hours will be spent on a matter and further, that this rating system unjustly rewards incompetent practitioners who need to spend more time on matters due to their lack of

${ }^{88}$ In Price Waterhouse Coopers Inc $v$ National Potato Co-operative Ltd (448/2003) [2004] ZASCA 64; [2004] 3 All SA 20 (SCA (1 June 2004) the court notes at par 23 that "At common law agreements that are contrary to public policy are void and not enforceable. While public policy generally favours the utmost freedom of contract it does take into account the necessity for doing "simple justice between man and man". Therefore, when a court finds that an agreement is contrary to public policy it should not hesitate to say so and refuse to enforce it. However, the court should exercise this power only in cases where the impropriety of the transaction and the element of public harm are manifest. It is an important consideration that there be certainty about the validity of agreements and that this certainty could be undermined by an arbitrary and indiscriminate use of the power to declare agreements contrary to public policy (see Sasfin (Pty) Ltd v Beukes 1989 (1) SA 1 (A))." In this case, where the litigant was provided with funds by another in return for a share of the proceeds of litigation, the agreement was found not to be contrary to public policy.

89 In Tjatji v Road Accident Fund, Khosa $v$ Road Accident Fund and Mxolisi v Road Accident Fund (2010/22475,2006/4412, 2009/11632) [2012] ZAGPJHC 198; 2013 (2) SA 632 (GSJ) (19 October 2012) par 19, the court stated that for a contingency agreement to be valid, the client must have "a proper understanding of the financial implications of the agreement. This can only be achieved if before signature of the contingency fee agreement the parties agree on the following matters: What will be regarded as constituting success or partial success, the circumstances in which the legal practitioner's fees and disbursements relating to the matter are payable; the amounts payable and method to be used in calculating such amounts; the manner in which disbursements made or incurred by the legal practitioner on behalf of the client are to be dealt with. Agreement also has to be reached in regard to the manner in which any amendment or agreement ancillary to the contingency fee agreement will be dealt with".

90 Rule 67 is headed "Tariff of Court Fees" and relates to court fees payable in respect of various provincial and local divisions. Rule 68 deals with the tariff applicable to Sheriffs and Rule 69 sets out the tariff of maximum fees for advocates on the party and party basis in civil matters. Rule 70 relates to the taxation and tariff of fees of attorneys. Rule 70 notes that the taxing master shall be competent to tax any bill of costs for services actually rendered by an attorney in his capacity as such in connection with litigious work and that the bill will be taxed in accordance with the tariff provided. The taxing master must allow all costs, charges and expenses as appear to him to have been necessary or proper for the attainment of justice or for defending the rights of any party, but will not allow costs which appear to have been incurred or increased through overcaution, negligence or mistake (Rule 70(3)). 
expertise. ${ }^{91}$ The set tariffs that are to be introduced under the auspices of the Legal Practice Bill are also open to criticism along the lines that a "one size fits all" approach does not take into account the vagaries of litigation. The shortcomings of these rating systems highlight the value of contingency fee arrangements, and the prevalence of these arrangements necessitated the introduction of the Contingency Fee Act. Teething problems aside, the Act can be seen as a positive step particularly in light of the supervisory role which our Courts have retained.

\section{CONCLUSION AND RECOMMENDATIONS}

The issue of how to achieve access to justice in the current legislative framework is a complex one. Because of the dissymmetry of information, attorneys are always in a more advantageous position as they are the experts who have the experience in settling personal injury claims. Their experience enables them to foresee to a great extent what exactly will be required of them in terms of personal services, how best to achieve a good settlement for a client and, provided that the defendant is not the embattled and neglectful Road Accident Fund, approximately how long it will take to settle a claim. Many attorneys do conduct themselves professionally and in many respects become a lifeline to indigent, disabled clients, and when it comes to billing, are able to account for the fees they charge. Therefore, it does seem that the best way to handle these matters is to ensure that attorneys comply with the stipulations of the Legal Practice Act. In addition, where a case is taken on in terms of a contingency agreement, the attorney should comply with the format as prescribed in the Contingency Fees Act. It seems that there is an overlap between the Contingency Fees Act and the new Legal Practice Act, and that is a matter that should be addressed. It makes more sense to incorporate the Contincengy Fees Act into the new Legal Practice Act in order to close all possible loopholes.

It is also suggested that regardless of whether the Contincency Fees Act continues to exist or whether it is in fact incorporated into the Legal Practice Act, the schedule to the Contingency Fees Act that constitutes the pro forma agreement between an attorney and a client should be reviewed. By redrafting the agreement in plain language, many of the aspects that are apparently not clear can be properly communicated to the client. That will leave no room for unfair treatment and there can be no uncertainty as to what a client may expect to pay upon completion of a case.

91 Buchner "Calculating Legal Costs: Changing the Way We Charge" October 2014 De Rebus 194; and Jele "The LPB, Costs and Fees Scrutinized at LSNP Workshop" August 2014 De Rebus 6. 